\title{
ANALISIS NOVEL 5 CM KARYA DONNY DHIRGANTORO DENGAN PENDEKATAN SEMIOTIK
}

\author{
Kartini $^{1}$, Sarwit Sarwono ${ }^{2}$, dan Bustanuddin Lubis ${ }^{3}$ \\ ${ }^{1,2,3}$ Program Studi Pendidikan Bahasa dan Sastra Indonesia \\ Jurusan Pendidikan Bahasa dan Seni \\ FKIP Universitas Bengkulu \\ kartinizulya@gmail.com
}

\begin{abstract}
Abstrak
Penelitian ini bertujuan untuk mengetahui angka dan maknanya yang terdapat di dalam novel $5 \mathrm{~cm}$ karya Donny Dhirgantoro. Metode yang digunakan dalam penelitian ini adalah metode kualitatif. Pendekatan yang dilakukan dalam penelitian ini adalah pendekatan semiotik. Hasil yang diperoleh dalam penelitian ini adalah angka dan maknanya yang terdapat di dalam novel $5 \mathrm{~cm}$ Karya Donny Dhirgantoro yang dikategorikan ke dalam tiga jenis tanda. Pertama, ikon, yaitu berlima, maknanya lima orang yang sudah bersahabat semenjak lama, selalu bersama-sama, dan tidak memiliki teman lain. Empat pria berarti empat orang pria yang menaiki kereta tidak membeli tiket. Kedua, indeks, yaitu satu tujuan berarti kebersamaan, disebabkan oleh kekompakan dan sudah berteman sejak lama. Ketiga, simbol, yaitu tiga menit maknanya kesepakatan yang dibuat oleh empat sahabat (kecuali lan) jika terpaksa mengatakan kejelekan atau keburukan orang lain. $5 \mathrm{~cm}$ maknanya lima orang sahabat yang tidak pernah menyerah untuk mengapai cita-citanya. Penelitian ini dapat disimpulkan bahwa angka dan maknanya yang terdapat di dalam novel $5 \mathrm{~cm}$ karya Donny Dhirgantoro adalah sebagai berikut: ikon, yaitu berlima, satu mangkok, satu orang dua lembar, tiga-tiga, satu orang, dua tangan, dua makhluk besar, empat pria, tiga macam, dan tiga bulan. Indeks, yaitu satu tujuan. Simbol, yaitu tiga menit, satu sama lain, arah jam sembilan, arah jam enam, dua alam, enam titik kecil, seribu wajah, 5 centimeter, seribu kali, jenis ketiga, dan ada satu.
\end{abstract}

\section{Kata Kunci: Analisis, Semiotik, Novel $5 \mathrm{~cm}$}

\begin{abstract}
Abstrack
This research goals for understand figure and meaning the get in interior novel $5 \mathrm{~cm}$ by Donny Dhirgantoro. The method use interior research this is method qualitative. The approachment do interior in research is approachment semiotic. The Product obtained interior this research is figure and the meaning do this interior novel $5 \mathrm{~cm}$ by Donny Dhirgantoro the category to interior three species sign. Firts, icon, five meaning five people the already be friend since long, alway do together, and not possess friend other. Four man meaning four people man the ride carriage not buy the ticket. Second, index that is one purpose meaning togetherness, caused by already be friend since long. Third, symbol, is three minutes meaning agreement reached the in made by for sahabat (except lan) if perforce say that ugliness or vice other people. $5 \mathrm{~cm}$ meaning people five friend the not never give up for the ideals of. The research can conclusion that figure and meaning that get in novel $5 \mathrm{~cm}$ karya Donny Dhirgantoro is: icon, that is five, one bowl, one people two sheet, three-three, one people, two hand, two great creature, four man, three kind, and three month. Index, that is one goals. Symbol, that is three minutes, one same other, direction at
\end{abstract}

JURNAL KorPus, Volume I, Nomor I, Agustus 2017 
nine o'clock, direction at six o'clock, two worl, six the point of small, a thousand face, 5 centimeter, a thousand times, the kind third, and there's one.

Keyword: analysis, semiotic, novel $5 \mathrm{~cm}$

\section{PENDAHULUAN}

Sastra adalah kegiatan seni yang diciptakan untuk mengungkapkan perasaan yang di alami oleh seseorang atau tentang masyarakat tertentu baik sesuai dengan pengalaman pengarang maupun secara imajinasi, hal ini sesuai dengan pendapat Sumardjo mengatakan bahwa Sastra adalah karya dan kegiatan seni yang berhubungan dengan ekspresi dan penciptaan (Sumardjo, 1997:1). Sastra yang telah dituangkan oleh pengarang ke dalam bentuk puisi, cerpen, dan novel sehingga menjadi sebuah karya sastra. Karya sastra adalah hasil kreatif seseorang yang akan disampaikan kepada pembaca, berupa puisi, cerpen, maupun novel. Di dalam karya sastra biasanya pengarang menggunakan majas dan kata kiasan untuk membuat pembaca tertarik. Karya sastra yang diciptakan oleh pengarang mengandung tanda-tanda yang sering ditemui dalam kehidupan sehari-hari, seperti lalu lintas, pesta pernikahan, kematian, maupun tanda alam. Hal ini sesuai dengan pendapat Pradopo dalam buku Kritik Sastra Indonesia Modern mengatakan bahwa karya sastra merupakan struktur yang bermakna mengingat karya sastra merupakan sistem tanda yang mempunyai arti (Pradopo, 2002:271).

Sebuah pengungkapan imajinasi maupun pengalaman pengarang yang dituangkan ke dalam bentuk novel yang akan disampaikan kepada pembaca dan membuat pembaca merasa benar-benar mengalami sesuai yang dibacanya di dalam novel. Novel adalah rangkaian cerita yang panjang, berkisah tentang kehidupan seseorang dengan masyarakat disekitarnya, di dalam isi cerita yang disampaikan tersebut mempunyai tema, amanat, alur, tokoh, dan setting. Hal ini juga sama dengan pendapat Sayuti dalam buku Berkenalan dengan Prosa Fiksi yaitu, Novel cenderung bersifat expands "meluas", novel cenderung menitikberatkan munculnya complexity "kompleksitas", novel tidak dapat dibaca dalam sekali duduk karena panjangnya, sebuah novel secara khusus memiliki peluang yang cukup untuk mempermasalahkan karakter tokoh dalam sebuah perjalanan waktu dan kronologi (Sayuti, 2000:10).

Di dalam novel terdapat tandatanda, tanda-tanda tersebut berupa judul, tokoh, alur, setting, dan peristiwa yang terjadi dalam novel. Seperti yang ditulis didalam buku Zoest (1993:61), teks sastra keseluruhan merupakan tanda dengan semua cirinya: pembaca, teks sastra ini menggantikan sesuatu yang lain, yakni kenyataan yang dipanggil, yang fiksional. Hal yang sama juga dikatakan oleh Ratna (2013:117) karya sastra atau naskah merupakan proses komunikasi yang dapat dipahami semata-mata dalam kaitannya dengan pengirim dan penerima.

Makna tanda-tanda bukanlah milik dirinya sendiri, tetapi berasal dari konteks yang diciptakan, dan tertanam. Novel yang akan peneliti teliti terdapat tanda-tanda maka penelitian ini dilakukan dengan mengunakan pendekatan semiotik. Semiotika adalah cabang ilmu yang berurusan dengan pengkajian tanda dan segala sesuatu yang berhubungan dengan tanda, seperti sistem tanda dan proses yang berlaku bagi penggunaan tanda (Zoest, 1993:1). Menurut (Endraswara, 2003:64), Semiotik berasal dari kata Yunani: semeion yang berarti tanda. 
Semiotik adalah model penelitian sastra dengan memperhatikan tanda-tanda. Tanda-tanda tersebut dianggap mewakili sesuatu objek secara representatif.

Menurut Pierce dalam Endraswara ada tiga jenis tanda berdasarkan hubungan tanda dengan yang di tandakan, yaitu: (1) ikon, yaitu tanda yang secara inheren memiliki kesamaan dengan arti yang ditunjuk. Misalnya, foto dengan orang yang difoto atau peta dengan wilayah geografisnya (Endraswara, 2003:65). Tanda ikon adalah tanda yang ada sedemikian rupa sebagai kemungkinan, tanpa tergantungan pada adanya sebuah denotatum, tetapi dapat dikaitkan dengan dasar suatu persamaan yang secara potensial dimilikinya. Tanda-tanda ikonis adalah tanda yang mengambarkan dengan sesuatu yang telah dikenal. Persamaan dengan suatu yang telah dikenal memberikan rasa aman (Zoest, 1993:24:25). (2) indeks yaitu tanda yang mengandung hubungan kausal dengan apa yang ditandakan. Misalnya, asap menandakan adanya api, mendung menandakan akan turun hujan (Endraswara, 2003:65). Sebuah indeks adalah sebuah tanda yang dalam hal corak tandanya tergantung dari adanya sebuah denotatum. Tanda-tanda indeksikal adalah tanda-tanda yang menunjuk (merujuk). Tanda ini bersandar pada keadaan terbatas (berdampingan, bersebelahan) secara eksistensial terbesar (Zoest, 1993:24:25). (3) Simbol yaitu tanda yang memiliki hubungan makna dengan yang ditandakan bersifat arbiter, sesuai dengan konvensi suatu lingkungan sosial tertentu. Misalnya, bendera putih sebagai simbol ada kematian (Endraswara, 2003:65). Simbol (lambang) adalah tanda yang berhubungan antara tanda dan denotatumnya ditentukan oleh suatu peraturan yang berlaku umum. Tanda simbolis adalah tanda-lewat-perjanjian. Karena tanda ini lebih baik terikat pada yang sosial maupun terpaksa lebih halus (Zoest, 1993:24-25).

Berdasarkan latar belakang di atas, rumusan masalah dapat dirincikan menjadi: (1) Angka yang terdapat di dalam novel $5 \mathrm{~cm}$ karya Donny Dhirgantoro? (2) Makna angka yang terdapat di dalam novel $5 \mathrm{~cm}$ karya Donny Dhirgantoro?

Berdasarkan rumusan masalah di atas, penelitian ini bertujuan sebagai berikut: (1) Untuk mengetahui angka yang terdapat di dalam novel $5 \mathrm{~cm}$ karya Donny Dhirgantoro. (2) Untuk mengetahui makna angka yang terdapat di dalam novel $5 \mathrm{~cm}$ karya Donny Dhirgantoro.

Penelitian ini bermanfaat untuk memberikan informasi kepada pembaca mengenai angka dan makna nya yang terdapat di dalam novel $5 \mathrm{~cm}$ karya Donny Dhirgantoro, dan menjadi semangat hidup, memberi motivasi, optimis, dan tidak pantang menyerah.

\section{METODE}

Penelitian ini menggunakan metode kualitatif. Metode kualitatif adalah sebagai prosedur penelitian yang menghasilkan data deskriptif berupa kata-kata tertulis atau lisan dari orang-orang dan perilaku yang dapat diamati (Bogdan dan Taylor dalam Moleong, 1989:3). Pendekatan yang digunakan di dalam penelitian ini adalah pendekatan semiotik.

Data untuk penelitian ini, didapat dari novel $5 \mathrm{~cm}$ karya Donny Dhirgantoro berupa teks-teks yang memiliki makna konotatif atau bukan makna sebenarnya. Sumber data yang digunakan dalam penelitian ini adalah novel $5 \mathrm{~cm}$ karya Donny Dhirgantoro, cetakan kedua puluh delapan tahun 2013, diterbitkan oleh PT Gramedia Widiasarana Indonesia.

Teknik pengumpulan data dalam penelitian ini menggunakan teknik studi pustaka. Teknik analisis di dalam penelitian ini adalah sebagai berikut; membuat 
sinopsis, mengidentifikasi, memaknai, dan membuat kesimpulan.

\section{HASIL DAN PEMBAHASAN}

Hasil dan pembahasan di peroleh di dalam penelitian ini adalah (1) Sinopsis novel $5 \mathrm{~cm}$ karya Donny Dhirgantoro, yaitu: novel $5 \mathrm{~cm}$ karya Donny Dhirgantoro menceritakan lima sahabat yang selalu bersama-sama yaitu Arial, Riani, Genta, Ian, dan Zafran. Pada suatu ketika lima sahabat ini berencana untuk tidak bertemu selama tiga bulan, Selama tiga bulan tidak bertemu lima sahabat mengejar dan mengapai mimpi masing-masing, Ian melanjutkan skripsi, Riani baru sebulan magang sudah dipercayai memegang liputan, Arial yang tidak terlalu banyak punya pengalaman dengan wanita, sudah satu bulan mengenal Indy lebih dekat, Genta sukses melaksanakan pameran komputer memakai nuansa Jungle Adventure, Zafran menyelesaikan pesanan desain untuk kampanye sebuah partai politik. Lima sahabat bertemu kembali pada tanggal 14 Agustus. (2) Identifikasi Angka-Angka yang terdapat dalam Novel 5 CM Karya Donny Dhirgantoro, yaitu;

Penelitian dalam novel $5 \mathrm{~cm}$ karya Donny Dhirgantoro, menemukan angka dan makna angka dikategorikan ke dalam tiga jenis tanda yaitu, pertama, ikon adalah makna yang memiliki kesamaan dengan objek. Tanda yang termasuk dalam kategori ikon memiliki makna yang mirip dengan objek yang di tunjukkan.

Angka yang merupakan kategori ikon, adalah (1) berlima, merupakan gambaran lima sahabat yang menyebut diri mereka sebagai power rangers. Lima sahabat yang sudah berteman sejak SMA, selalu bersama kemana-mana dan tidak mempunyai teman lain selain dari kumpulan power rangers. Hal ini dibuktikan oleh kutipan; "Mungkin kita emang harus ngeliat dunia lain di luar tongkrongan kita dulu, jangan berlima melulu ke mana-mana." (Dhirgantoro, 2013:63).

(2) Satu mangkok merupakan gambaran setiap kali lan datang ke rumah teman-temannya, pasti meminta pembantu temannya membuatkan indomie. Setiap Ian meminta indomie pasti disiapkan untuk Riani minta kuah, Hal ini dibuktikan oleh kutipan; "Riani mengambil satu mangkok kosong yang emang udah disiapin oleh pembantu arial, hasil pengajaran Genta tentang service excellent (Dhirgantoro, 2013:54).

(3) Satu orang dua lembar, kuisioner yang akan disebarkan oleh lan di tempat tujuan penelitiannya. Hal ini dibuktikan oleh kutipan berikut ini; "Ini kuesionernya, semua ada dua ratus lembar, satu orang dua lembar. Ini surat izin penelitian dari kampus." (Dhirgantoro, 2013:119).

(4) Tiga-tiga, kursi kereta api yang di naiki lima sahabat dalam perjalanan mendaki puncak Mahameru. hal ini dibuktikan oleh kutipan berikut; "Ini tempat duduk kita," kata Genta, "Pas enam orang hadap-hadapan tiga-tiga. Tas taruh di atas atau di bawah aja." (Dhirgantoro, 2013:150).

(5) Satu orang, topik pembicaraan Zafran dan Genta di Gerbong kereta api, bahwa pada zaman Socratos ada seseorang yang berani keluar dari zona nyaman dan melakukan hal yang baru. Hal in dibuktikan oleh kutipan berikut; "Suatu hari ada satu orang yang akhirnya keluar dari gua itu dan menemukan bahwa ternyata di luar sana banyak keindahan sejati yang menunggu mereka di dunia nyata, tanah, air, sungai-sungai, dan kehidupan yang lebih indah (Dhirgantoro, 2013:157).

(6) Dua tangan, Genta yang menggunakan dua tangannya untuk menunjukkan sesuatu. Hal ini dibuktikan oleh kutipan berikut; "Tapi kayaknya kalo disimpulin begini, benerin gue kalo salah. Zaman sekarang banyak orang yang hidup 
tapi nggak bener-bener 'hidup' kata Genta sambil mengangkat dua tangannya dan jarinya memberi tanda kutip pada kata hidup (Dhirgantoro, 2013:159).

(7) Dua makhluk besar, Ian dan Arial yang ingin bercerita tentang pengalaman yang didapatnya selama tidak bertemu dengan teman-temannya. Hal ini dibuktikan oleh kutipan berikut; "Di antara mereka berenam, ada dua makhluk besar yang dari tadi menahan segala luapan emosinya untuk bercerita, sesuatu yang fantastis, yang ingin mereka bagi, kedua makhluk itu lan dan Arial (Dhirgantoro, 2013:163-164).

(8) Empat pria, empat orang yang menaiki kereta tetapi tidak membeli tiket di stasiun. Hal ini dibuktikan oleh kutipan berikut; "Karcis, Mas... tiket!" petugas akhirnya bicara agak galak. "Ore nduwe, Pak..." (nggak punya, Pak) kata salah satu dari mereka. (Dirgantoro, 2013:186).

(9) Tiga macam, topik pembicaraan lima sahabat di Ranu Kombolo bahwa di dunia ini tidak ada yang benar-benar pasti, dan jika mau berusaha bisa mendapatkan apa yang kita inginkan. Hal ini dibuktikan kutipan berikut; "Riani diam sebentar, lalu meneruskan, "Maut atau kematian bisa kapan aja datang... contohnya udah banyak banget. "Rezeki? Rezeki katanya ada tiga macam, rezeki yang ada semenjak kita lahir, rezeki yang kita punya sekarang, dan rezeki yang ditangguhkan. Jadi, Sebenarnya kita punya rezeki yang ditangguhkan, yang kalo kita mau, bisa kita kejar (Dhirgantoro, 2013:269).

(10) Tiga bulan, selama tiga bulan lima sahabat sepakat tidak bertemu, selama tidak bertemu lan menyelesaikan skripsinya. Ariani baru sebulan magang, sudah dipercayai memegang liputan, Genta melaksanakan pameran komputer memakai nuansa Jungle Adventure. Arial selama tidak bertemu dengan temantemannya memutuskan untuk mengenal Indy lebih dekat, wanita yang dikenalnya di tempat fitness, dan Zafran sedang menyelesaikan pesanan desain untuk kampanye sebuah partai politik yang sangat terkenal. Hal ini dibuktikan oleh kutipan berikut; "“Tiga bulan dari sekarang itu kapan yah...tanggal berapa?" "14 Agustus," Arial menjawab pertanyaan lan. (Dhirgantoro, 2013:64).

Kedua, indeks yaitu tanda yang mempunyai hubungan sebab akibat. Kategori indeks adalah satu tujuan. Lima sahabat selalu bersama-sama dan telah bersahabat sejak lama, walaupun mereka memiliki hobi dan kesukaan berbeda-beda. Tetapi memiliki satu tujuan seperti tempat berkumpul bersama, makan bersama. Hal ini dibuktikan oleh kutipan berikut ini:

"Mereka sepakat, untuk entah berapa kalinya, pergi ke rumah Arial dengan satu tujuan: bermain Monopoli" (Dhirgantoro, 2013:19).

Ketiga, simbol yaitu tanda yang memiliki hubungan makna dengan yang ditandakan bersifat arbiter. Sesuai dengan ketentuan atau kesepakatan masyakat. Kategori simbol adalah (1) tiga menit, sebagai rumus empat sahabat yang tidak mau mengatakan kejelekan orang lain, jika orangnya tidak ada. Waktu itu lan belum bergabung dengan keempat temannya, masih labil, dan tidak menjadi diri sendiri. lan hanya mengikuti apa yang disukai orang lain walaupun sebenarnya ia tidak suka. Jadi keempat sahabat tersebut berencana akan mendatangi rumah Ian untuk membahas sifat lan yang labil dan tidak menjadi diri sendiri. Hal ini dibuktikan oleh kutipan berikut; "Pakai tiga menit nggak?" tiba-tiba Genta nanya lagi. "Pakai lah...." (Dhirgantoro, 2013:43).

(2) Satu sama lain, Ian menyuruh Genta segera mengatakan rasa cintanya ke Riani, karena sudah saatnya Genta mengatakan perasaannya ke Riani, selama berteman Genta sudah sangat cocok dan ia juga mencintai Riani melebihi sahabat. Akan tetapi Genta ragu mengatakan 
kepada Riani, karena mereka sudah sangat dekat sebagai sahabat, dan mengerti satu sama lain. Hal ini dibuktikan oleh kutipan; "Gue mau tunjukkin ke Riani, gimana? Kayaknya udah saling ngerti satu sama lain, udah terlalu deket, Yan." (Dhirgantoro, 2013:239).

(3) Arah jam sembilan, dan (4) arah jam enam, Dinda melihat sekeliling warung, ternyata laki-laki semua. Tiba-tiba Riani menyenggol bahu Dinda sambil mengatakan bahwa di warung itu juga ada wanita yang berarti tidak hanya Riani dan Dinda wanita yang ikut mendaki puncak Mahameru. hal ini dibuktikan oleh kutipan berikut; "Dinda, sebelah kiri lo, arah jam sembilan." Dinda pun menoleh, serombolan cewek berjilbab tampak bergerombol bersama satu meja (Dhirgantoro, 2013:219). "Arah jam enam," Riani berkata lagi. Riani dan Dinda melihat lagi tiga orang wanita dan empat orang laki-laki sedang menikmati makan malamnya. "Lumayan banyak juga ya cewek yang mau naik ke Mahameru (Dhirgantoro, 2013:219).

(5) Dua alam, Ian dan Zafran menunggu semua teman-temannya sampai di bukit cinta, setelah temantemannya sampai di atas bukit, mereka melihat padang ilalang yang luas masih melambai-lambai tertiup angin. Melihat padang ilalang Arial merasa berada di dua alam yang berbeda karena pemandangan didepannya sangat indah dan ia baru pertama kali melihat pemandangan seindah itu. Di Mahameru mereka mendapatkan banyak sekali kejutan. Hal ini dibuktikan oleh kutipan berikut; "Fiuh... Mahameru, Mahameru... banyak banget kejutannya. Nggak ada yang biasa lagi." Dinda menggeleng-gelengkan kepalanya. Arial merasa sedang berada di dua alam yang berbeda (Dhirgantoro, 2013:286).

(6) Enam titik kecil, Sampai di padang ilalang, Riani mengeluarkan handycam dan mulai merekam. Arial mencolek pundak Riani dan memberikan tanda dengan jempolnya agar Riani melihat ke belakang, Ranu Kumbolo dan padang Ilalang juga terekam. Beberapa saat kemudian, rombongan itu melanjutkan perjalanannya dan memilih melewati padang yang ada jalan setapaknya. Rombongan itu menuruni jalan setapak yang mengakhiri bukit. Mereka beriringan berjalan di antara keindahan alam Mahameru. hal ini dibuktikan oleh kutipan berikut; "Dari atas mereka mirip enam titik kecil berjalan beriringan di antara keindahan alam Mahameru, membelah semesta dengan segala keindahan di sekeliling mereka (Dhirgantoro, 2013:288).

(7) Seribu wajah, Pukul setengah tiga lebih, mereka berenam menuju kereta yang siap berangkat. Kereta ekonomi Matarmaja yang melayani trayek MalangJakarta. Mereka memasuki gerbong kereta yang saat itu sudah banyak penumpang dengan tampang kepanasan. Di dalam kereta ada penumpang yang berkipaskipas, nenek tua yang berkerudung kotor transparan seadanya. Mereka duduk di kursi penumpang yang hanya pas untuk enam orang. Penumpang di Kereta itu membuat hati enam sahabat itu tersentuh. Hal ini dibuktikan oleh kutipan berikut; "Nenek tua dengan kerudung kotor transparan seadanya, bapak setengah baya dengan anak kecilnya yang menangis, ibu muda yang sedang menyusui bayinya, bapak tua dengan safari lusuh dan peci... seribu wajah yang menyentuh hati mereka (Dhirgantoro, 2013:150).

(8) 5 centimeter, untuk meraih mimpi dan cita-citanya. Lima sahabat tidak pernah melepas lima centimeter di dalam hidupnya. Hal ini dibuktikan oleh kutipan berikut; "Lo selalu pake 5 centimeter? "Selalu.... "Sama.... dan gue percaya itu,", "Nggak pernah gue lepas." "Nggak pernah ilang." (Dhirgantoro, 2013:377). 
(9) Seribu kali, tekad yang keras akan mewujudkan impian dan cita-cita, sebagai manusia hanya melakukan apa yang bisa ia lakukan, selebihnya hanya harus yakin, dan pantang menyerah. Hal ini dibuktikan oleh kutipan berikut: "Lapisan tekad yang seribu kali lebih keras dari baja....", "Dan hati yang akan bekerja lebih keras dari biasanya...." (Dhirgantoro, 2013:362-363).

(10) Jenis ketiga, pembicaraan lima sahabat tentang kebaikan dan keburukan, Zafran melanjutkan manusia terbagi menjadi tiga yaitu orang baik yang melakukan segala hal dengan ikhlas, orang jahat yang menghalalkan segala cara untuk melakukan kejahatannya. Zafran melanjutkan lagi orang ketiga yaitu orang yang selalu membuat pernyataanpernyataan atau orang yang selalu mencari jawaban tentang kebaikan dan keburukan. Sampai akhirnya Arial bertanya apakah orang jenis ketiga benar-benar ada di dunia ini. Hal ini dibuktikan oleh kutipan berikut; "Tapi orang jenis ketiga itu emang ada kan? Lo liat di sekitar lo deh," Arial bertanya (Dhirgantoro, 2013:268).

Simbol yang terakhir, (13) ada satu, bahwa di dunia ini tidak ada yang pasti. Semuanya bisa berubah, jika mau berusaha. Pepatah mengatakan tidak ada usaha yang mengkhianati hasil artinya tidak ada usaha yang sia-sia. Hal ini dibuktikan oleh kutipan berikut; "Kalau kita perhatikan, enggak pernah ada satu yang pasti banget di dunia ini, kecuali ketidakpastian itu sendiri. Jodoh, rezeki, dan maut, semuanya nggak pasti." (Dhirgantoro, 2013:269).

Simbol yang digunakan di dalam novel $5 \mathrm{~cm}$ karya Donny Dhirgantoro berdasarkan sesuatu yang ingin disampaikan pengarang kepada pembaca.

(3) Memaknai tanda yang terdapat di dalam novel $5 \mathrm{~cm}$ karya Donny Dhirgantoro dengan menggunakan triangle meaning atau segitiga makna adalah sebagai berikut: pertama ikon, (1) berlima berarti lima orang sahabat yang selalu bersamasama, sehingga mereka tidak mempunyai teman lain. Hal ini dibuktikan oleh kutipan berikut; "kita emang harus ngeliat dunia lain di luar tongkrongan kita dulu, jangan berlima melulu ke mana-mana" (Dhirgantoro, 2013:63).

(2) Satu mangkok berarti satu mangkok kosong yang disiapkan untuk Riani meminta Kuah indomie, ketika lan datang ke rumah teman-temannya. Hal ini dibuktikan oleh kutipan berikut; "Kuahnya dong...," Riani mengambil satu mangkok kosong yang emang udah disiapin oleh pembantu Arial (Dhirgantoro, 2013:54).

(3) Satu orang dua lembar berarti lembaran kertas kuisioner penelitian Ian yang dibagikan di tempat penelitiannya. Hal ini dibuktikan oleh kutipan berikut; "Ini kuesionernya, semua ada dua ratus lembar, satu orang dua lembar. Ini surat izin penelitiannya dari kampus." (Dhirgantoro, 2013:119).

(4) Tiga-tiga berarti tempat duduk di kereta api yang berhadap-hadapan tigatiga. Hal ini dibuktikan oleh kutipan berikut; "Pas enam orang hadap-hadapan tiga-tiga. Tas taruh di atas atau di bawah aja. "Sempit-sempitan gini?" Protes Ian (Dhirgantoro, 2013:150).

(5) Satu orang berarti selama perjalanan menuju puncak Mahameru, lima sahabat itu mengatakan di zaman Socratos ada satu orang yang berani keluar dari zona aman dan berani meninggalkan kebiasan demi belajar hal yang baru. Hal ini dibuktikan oleh kutipan: "Suatu hari ada satu orang yang akhirnya keluar dari gua dan menemukan bahwa ternyata di luar sana banyak keindahan sejati yang menunggu mereka di dunia nyata, tanah, air, sungai-sungai, dan kehidupan yang lebih indah (Dhirgantoro, 2013:157).

(6) Dua tangan berarti Genta menggunakan dua tangannya untuk memberi tanda kutip pada kata hidup yang dibicarakannya bersama dengan Zafran. 
Hal ini dibuktikan oleh kutipan berikut; "Zaman sekarang banyak orang yang hidup tapi nggak benar-benar 'hidup' kata Genta sambil mengangkat dua tangannya dan jarinya memberi tanda kutip pada kata hidup (Dhirgantoro, 2013:159).

(7) Dua makhluk besar berarti selama perjalanan menuju puncak Mahameru, Ian dan Arial ingin mengatakan apa yang telah mereka peroleh selama tidak bertemu dengan teman-temannya. $\mathrm{Hal}$ ini dibuktikan oleh kutipan berikut: $\mathrm{Di}$ antara mereka berenam, ada dua makhluk besar yang dari tadi menahan segala luapan emosinya untuk bercerita." (Dhirgantoro, 2013:163).

(8) Empat pria berarti empat orang pria yang menaiki kereta tidak membeli tiket terlebih dahulu di stasiun dan terpaksa membayar tiket sebesar dua puluh ribu rupiah. Hal ini dibuktikan oleh kutipan berikut; "Pira, Pak? Papat!" (Berapa, Pak? Empat) lanjut si pemuda memasukkan tangannya ke saku belakang siap mengambil dompet. "Larang tenan, Pak... ning stasiun telung ewu lima ngatus sak wong." (Mahal banget, pak... di stasiun aja tiga ribu lima ratus seorang). (Dhirgantoro, 2013:186).

(9) Tiga macam berarti di dunia ini semuanya adalah pilihan, jika mau berusaha maka apapun yang kita inginkan bisa didapatkan. Hal ini dibuktikan oleh kutipan berikut; "Rezeki? Rezeki katanya ada tiga macam, rezeki yang ada semenjak kita lahir, rezeki yang kita punya sekarang, dan rezeki yang ditangguhkan (Dhirgantoro, 2013:269).

(10) Tiga bulan berarti selama tiga bulan lima sahabat tersebut tidak bertemu untuk meraih mimpi dan cita-cita masingmasing. Hal ini dibuktikan oleh kutipan berikut; "Tiga bulan dari sekarang itu kapan yah...tanggal berapa? "14 Agustus," Arial menjawab pertanyaan lan. "Mungkin kita emang harus ngeliat dunia lain di luar tongkrongan kita dulu, jangan berlima melulu ke mana-mana," kalimat Zafran tentang Plato barusan menyentakkan keapaadaan-nya diri Arial (Dhirgantoro, 2013:64)

Kedua, indeks yaitu satu tujuan yang disebabkan oleh lima sahabat yang kompak karena lima sahabat tersebut telah berteman semenjak SMA. Hal ini dibuktikan oleh kutipan berikut; "Mereka sepakat, untuk entah keberapa kalinya, pergi ke rumah Arial dengan satu tujuan: bermain monopoli (Dhirgantoro, 2013:19).

Ketiga, simbol yaitu (1) tiga menit berarti rumus yang digunakan empat sahabat (kecuali lan) jika terpaksa mengatakan kejelekan atau keburukan orang lain. Hal ini dibuktikan oleh kutipan berikut; "Jangan jelek-jelekin orang ya," kata Genta pelan. Genta saklek sama prinsip keempat sahabatnya ini. "Intinya aja deh...," Riani ikutan ngomong akhirnya. "Dan jangan lebih dari tiga menit," Genta memperjelaskan (Dhirgantoro, 2013:41).

(2) Satu sama lain berarti selama bersahabat lima sahabat itu sudah mengenal kepribadian, hobi, dan kesukaan teman-temannya. Hal ini dibuktikan oleh kutipan berikut; "Gue mau nunjukin ke Riani, gimana? Kayaknya udah saling ngerti satu sama lain, udah terlalu deket, Yan." (Dhirgantoro, 2013:239).

(3) Arah jam sembilan dan (4) arah jam enam berarti menunjukkan arah. Hal ini dibuktikan oleh kutipan berikut; "Dinda, sebelah kiri lo, arah jam sembilan." "Arah jam Enam," Riani berkata lagi. (Dhirgantoro, 2013:219).

(5) Dua alam berarti keindahan alam di perjalanan menuju puncak Mahameru membuat enam sahabat merasa sangat kagum dengan ciptaan Tuhan. Hal ini dibuktikan oleh kutipan berikut; "Gilee... gue kayak di Afrika." Nggak ada yang biasa lagi." Dinda menggeleng-gelengkan kepalanya. Arial merasa sedang berada di dua alam yang berbeda. (Dhirgantoro, 2013:286). 
(6) Enam titik kecil berarti enam orang yang berjalan beriringan menuju puncak Mahameru. hal ini dibuktikan oleh kutipan berikut; "Dari atas mereka mirip enam titik kecil berjalan beriringan di antara keindahan alam Mahameru, membelah semesta dengan segala keindahan di sekeliling mereka" (Dhirgantoro, 2013:288).

(7) Seribu wajah berarti keadaan orang-orang yang menaiki kereta bersama rombongan enam sahabat beserta orangorang yang mereka temui di stasiun kereta yang membuat hati mereka tersentuh. Hal ini dibuktikan oleh kutipan berikut; "Ibu setua ini, malam-malam masih mencari rezeki, ke mana anaknya? Dinda tambah tercekat melihat tangan hitam dan kurus itu menyiapkan nasi." "Dia sudah terlalu tua untuk semua ini, batin Genta berjalan pelan sekali, bingung dan nggak tega. Matanya menatap lampu-lampu kota Jogja di ujung rel kereta (Dhirgantoro, 2013:174). "Seribu wajah yang menyentuh hati mereka (Dhirgantoro, 2013:150).

(8) 5 centimeter berarti letakkan semua cita-cita dekat di depan mata, selanjutnya yakini semua itu, dan berusaha semampunya. Hal ini dibuktikan oleh kutipan berikut; "Jadi kalo kita yakin sama sesuatu, kita Cuma harus percaya, terus berusaha bangkit dari kegagalan, jangan pernah menyerah dan taruh keyakinan itu di sini...." Zafran meletakkan telunjuk di depan keningnya (Dhirgantoro, 2013:361). Biarkan... Dia... Menggantung... Mengambang... 5 centimeter... (Dhirgantoro, 2013:362).

(9) Seribu kali berarti jika mempunyai cita-cita harus mempunyai tekad yang lebih keras dari baja untuk mewujudkannya. Hal ini dibuktikan oleh kutipan berikut; "Lapisan tekad yang seribu kali lebih keras dari baja....", "Dan hati yang akan bekerja lebih keras dari biasanya...." (Dhirgantoro, 2013:362).
(10) Jenis ketiga berarti di dalam kehidupan ini ada yang melakukan kejahatan dan kebaikan, ada juga yang melakukan keburukan kemudian ia bertobat. Hal ini dibuktikan oleh kutipan berikut; "Tapi orang jenis ketiga itu emang ada kan? Lo liat di sekitar lo deh," Arial bertanya. "Banyak, kadang-kadang dia melakukan hal yang baik, kadang-kadang dia melakukan hal yang buruk." (Dhirgantoro, 2013:268).

(11) Ada satu berarti di dalam kehidupan tidak ada yang pasti, hanya yang bersungguh-sungguhlah yang akan mendapatkan apa yang mereka inginkan. Hal ini dibuktikan oleh kutipan berikut; "Kalau kita perhatikan, nggak pernah ada satu yang pasti banget di dunia ini, kecuali ketidakpastian itu sendiri. Jodoh, rezeki, dan maut, semuanya nggak pasti." (Dhirgantoro, 2013:269).

\section{PENUTUP \\ Kesimpulan}

Berdasarkan penelitian yang telah dilakukan di dalam novel $5 \mathrm{~cm}$ karya Donny Dhirgantoro terdapat tanda semiotik yaitu, ikon, indeks, dan simbol. Lima sahabat yang sudah berteman sejak SMA dan selalu bersama kemana-mana. Lima sahabat di dalam novel $5 \mathrm{~cm}$ karya Donny Dhirgantoro mengajarkan kepada pembaca, menggunakan rumus tiga menit jika terpaksa mengatakan kejelekan orang lain, dengan tujuan untuk disampaikan kepada orang yang bersangkutan bahwa sikap dan perilakunya menyakiti orang lain.

Lima sahabat di dalam novel $5 \mathrm{~cm}$ menggunakan rumus 5 centimeter untuk mengapai, mewujudkan impian dan citacitanya, seperti lan yang mengejar target empat bab selama dua bulan, Riani yang baru sebulan magang sudah dipercayai memegang liputan, Genta sukses melaksanakan pameran komputer memakai nuansa Jungle Adventure. Sedangkan Arial dan Zafran tidak dijelaskan 
impian yang digapainya. Hanya dijelaskan selama sebulan Arial yang tidak memiliki pengalaman dengan wanita, sudah satu bulan mengenal Indy lebih dekat, wanita yang dikenalnya ditempat fitness.

\section{Saran}

Penelitian di atas tentang angkaangka yang peneliti temukan di dalam novel $5 \mathrm{~cm}$ karya Donny Dhirgantoro menggunakan pendekatan semiotik, peneliti menyarankan kepada meneliti selanjutnya agar memperhatikan setiap kalimat di dalam teks karya sastra, karya sastra banyak terdapat motivasi, makna yang tersirat, nasihat-nasihat, pengetahuan baru, dan untuk menambah wawasan pembaca, penelitian selanjutnya yang berhubungan dengan karya sastra novel pada bidang dan ruang lingkup yang berbeda.

\section{DAFTAR PUSTAKA}

Dhirgantoro, Donny. 2013. $5 \mathrm{Cm}$. Jakarta: PT Gramedia Widiasarana Indonesia.

Endraswara, Suwardi. 2003. Metodelogi penelitian sastra. Yogyakarta: Pustaka Widyatama.
Moleong, Lexy. 1989. Metode Penelitian Kualitatif. Bandung: PT. Remadja Karya CV.

Pradopo, Rachmat. 2002. Kritik Sastra Indonesia Modern. Yogyakarta: GAMA MEDIA.

Ratna, Nyoman Kutha. 2013. Statilistika Kajian Puitika Bahasa, Sastra, dan Budaya. Yogyakarta: Pustaka Pelajar.

Sayuti, Suminto. 2000. Berkenalan Dengan Prosa Fiksi. Yogyakarta: GAMA MEDIA.

Sumardjo, Jakob dan Saini K.M. 1997. Apresiasi Kesusastraan. Jakarta: PT. Gramedia Pustaka Utama.

Zoest, Aart van. 1993. Semiotika Tentang Tanda, Cara Kerjanya, dan Apa Yang Kita Lakukan Dengannya. Jakarta: Yayasan Sumber Agung. 